\title{
MENGENAL ARSITEKTUR LOKAL: KONSTRUKSI RUMAH KAYU DI TEPIAN SUNGAI KAPUAS, PONTIANAK
}

\section{Lestari}

Program studi Arsitektur, Universitas

Tanjungpura, Indonesia

lest_tazkiya@yahoo.com

\section{Rudiyono}

Program studi Arsitektur, Universitas

Tanjungpura, Indonesia

\author{
Zairin Zain \\ Program studi Arsitektur, Universitas \\ Tanjungpura, Indonesia
}

\begin{abstract}
Abstrak
Keberadaan sungai Kapuas sebagai sumber kehidupan dan jalur transportasi air, memunculkan permukiman-permukiman di tepian sungai Kapuas.Rumah-rumah yang berada di pemukiman tepian sungai Kapuas umumnya didirikan langsung di tepian sungai Kapuas.Rumah tersebut sebagian besar berupa rumah kayu yang terhubung dengan gertak-gertak sebagai jalur penghubung antar rumah.Konstruksi rumah kayu ini menarik untuk diamati mengingat keadaan tepian sungai perlu diselesaikan oleh bangunan agar tetap bertahan.Tulisan ini memaparkan kontruksi rumah kayu pada salah satu kasus daerah tepian sungai kapuas. Daerah kasus yang diambil adalah Kelurahan Bansir Laut, Kecamatan Pontianak Tenggara, Kota Pontianak.Dalam tulisan ini dipaparkan konstruksi kayu berdasarkan bagian-bagian rumah mulai dari pondasi, rangka, dinding, sampai atap.Terdapat beberapa tipe konstruksi pada kasus yang diteliti.Pertimbangan umum terletak pada kemudahan konstruksi, tampilan atau fasad dan lokasi keberadaan rumah.
\end{abstract}

Kata kunci: struktur, kayu, tepian sungai.

\begin{abstract}
The existence of the Kapuas river as a source of life and water transportation, led to settlements growth on side the Kapuas river. The houses are located on side Kapuas river are generally directly constructed at the river. The houses mostly made of wood which connected by wooden bridge as connecting lines between houses. Construction of wooden houseis interesting to be identifiedbecause the building must bedurable with the condition around the river. This paper describes the wooden houses construction in one case area of the Kapuas riverside. Case study is taken at Kelurahan Bansir Laut, South East Pontianak District. In this paper described the wooden construction: the foundation, frame, wall, and the roof. There are several types of construction in the cases studied. General considerations is the ease of construction, appearance or facade and location of the house.
\end{abstract}

Keywords: house, structure, wood, riverside. 


\section{Pendahuluan}

Tumbuhnya rumah-rumah di tepian sungai Kapuas merupakan tanggapan terhadap potensi sungai sebagai penunjang kehidupan.Air sebagai penunjang kehidupan mendorong masyarakat untuk hidup mendekati sumber air, termasuk sungai.Hidupnya jalur transportasi air yang menghubungkan suatu daerah dengan daerah lain sekaligus memperlancar arus barang dan jasa juga merupakan faktor munculnya pemukiman yang berada ditepian sungai. Sungai Kapuas merupakan sungai terpanjang yang tidak hanya digunakan sebagai jalur penghubung antara daerah-daerah di sekitar Pontianak, namun juga sebagai jalur penghubung antara daerah-daerah lain di Kalimantan barat.

Rumah-rumah yang dibangun didaerah tepian sungai mempertimbangkan iklim dan kondisi sekitar sungai yang harus dihadapi agar bangunan yang berdiri tetap bertahan.Kondisi pasang surut, gelombang air dan angin menjadi beban-beban yang harus dipikul oleh bangunan.Daerah tepian sungai ada yang mengering pada kondisi surut dan terendam pada kondisi pasang. Gelombang sungai akan besar jika jalur sungai tersebut dilalui oleh kendaraankendaraan air. Tanggapan bangunan terhadap kondisi sekitarnya memungkinkan bangunan dapat bertahan pada kondisi tersebut, hal ini karena kerusakan pada bangunan umumnya disebabkan oleh keadaan iklim dan cuaca setempat (Zain, 2012).

Salah satu konstruksi rumah yang banyak dibangun oleh masyarakat pemukiman tepian sungai adalah rumah kayu.Rumah ini ada yang dibangun di badan sungai, di tepian sungai yang dasar bangunan sebagian besar terendam dan di daratan tepian sungai yang relatif kering.Bangunan rumah kayu yang tumbuh di tepian sungai Kapuas tetap berkembang dan bertahan sampai saat ini.Keberadaan bangunan tersebut tentunya telah menyesuaikan dengan kondisi sekitar. Penggalian akan keunikan bangunan khususnya mengenai konstruksi bangunan yang berada ditepian sungai menarik untuk dipelajari lebih lanjut mengingat bangunan kayu tersebut harus menghadapi pasang surut air sungai beserta gelombang air sungai yang sentiasa terjadi sepanjang tahun.

\section{Konstruksi Rumah Kayu di Tepian Sungai Kapuas}

Menurut letak dan kondisi lokasi, bangunan tepian sungai dibagi menjadi tiga kategori (Dwinasari dalam Hidayat, 2014):

1. Rumah yang letaknya di badan sungai, selalu terapung di atas air, disebut rumah rakit.

2. Rumah yang letaknya di tepian sungai yang kondisinya tergantung dari pasang surut air sungai.

3. Rumah yang letaknya di tepian sungai yang lokasinya pada daerah relatif kering dengan kondisi tanah lembek/lunak serta berair apabila ada banjir musiman.

Rumah-rumah yang dibangun di tepian sungai Kapuas awalnya berupa rumah lanting kemudian berkembang menjadi rumah tiang.Perkembangan permukiman dan perubahan kondisi fisik tepian sungai mengubah konsep hunian rumah tinggal dari rumah lanting ke rumah tiang (Khaliesh dkk, 2012).Di tahun 1950-1970, Lanting sudah mulai berkurang keberadaannya.Rumah lanting adalah rumah yang selalu terapung di atas air atau dikenal juga dengan sebutan rumah rakit, sedangkan pada rumah tiang, konstruksi bangunan sudah diletakkan langsung di tanah baik itu selalu terendam air maupun dapat mengering pada musim atau kondisi tertentu. Baik rumah lanting maupun rumah tiang, bahan kayu merupakan bahan utama yang selalu digunakan.Perbedaan mendasar dari kedua rumah ini adalah pada pondasi yang digunakan.Rumah lanting menggunakan pondasi rakit yang selalu mengapung, sedangkan rumah tiang sudah menggunakan pondasi berupa tiang yang ditanamkan kedasar tanah. 
Bangunan tepian sungai dengan menggunakan bahan bangunan lokal akan dapat menciptakan keseimbangan ekologi di tepian sungai karena adanya adaptasi alami berupa hubungan timbal balik antara manusia alam dan hunian/arsitektur (Hidayat, 2014). Bahan kayu merupakan bahan lokal yang paling sering digunakan pada bangunan rumah-rumah tepian sungai Kapuas. Kayu yang berasal dari hutan/tanaman rakyat pada dasarnya dapat digunakan untuk berbagai keperluan baik untuk pertukangan maupun bahan bangunan (Abdurachman, 2006). Kayudapat digunakan pada hampir semua bagian bangunan, mulai dari pondasi, rangka, lantai dan dinding, sampai atap. Keistimewaan bahan kayu antara lain karena kekuatan yang dimiliki, keunggulannya dari segi visual, peredam suara, panas, ketahanan terhadap cuaca. Selain itu, kemudahan dan keterjangkauan harga, menjadi faktor lain bahan kayu sering digunakan.

Rumah-rumah kayu yang ada di Kalimantan Barat termasuk ditepian Sungai Kapuas umumnya berupa rumah tiang kayu yang dibangun dengan bahan kayu lain yang dimanfaatkan sebagai bahan dinding, lantai, tangga, rangka atap dan rangka plafond. Bahan kayu memang bahan yang mudah diolah menjadi berbagai bentuk dan ukuran untuk keperluan konstruksi dan dimanfaatkan untuk berbagai bagian bangunan seperti pondasi, lantai, atap, tangga, dinding, pintu dan jendela (Hidayati, 2012). Untuk keperluan kayu sebagai komponen bangunan, ukuran kayu biasanya dibentuk dengan ukuran standar seperti ukuran reng, kaso, balok-balok dan lainlain(Abdurachman,2006).Sistem konstruksi yang digunakan juga disesuaikan dengan keadaan iklim setempat untuk sehingga bangunan dapat menyesuaikan dengan kondisi yang harus dihadapi sepanjang tahun (Zain, 2012).

Pada konstruksi bangunan dengan menggunakan bahan kayu ada beberapa hal penting yang perlu dipertimbangkan.Sambungan kayu merupakan bagian penting untuk diperhatikan dalam suatu kontruksi kayu.Sambungan digunakan untuk memperoleh panjang atau lebar yang dibutuhkan atau membentuk suatu konstruksi tertentu.Perlu dipahami bahwa sambungan merupakan titik terlemah dari sebuah konstruksi. Oleh karena itu, perlu diperhatikan syaratsyarat ukuran sambungan dan gaya yang bekerja dalam melakukan penyambungan. Gaya-gaya yang harus diatasi dalam membuat sambungan (Puspantoro, 2005) adalah gaya tarik, gaya desak, puntir(torsi), dan gaya lintang (momen). Ada beberapa hal yang perlu diperhatikan untuk mendapatkan sambungan yang baik antara lain teknik pemasangan, meminimalkan kerusakan kayu, dan kemudahan untuk diperbaiki.Dalam konstruksi rumah yang dibangun secara tradisional oleh masyarakat umumnya mempertimbangkan kemampuan alami turun temurun yang dimiliki oleh masyarakat tradisional dengan tetap memperhatikan ketahanan strukturnya (Zain, 2014).Namun, faktor keawetan bahan kayu menjadi salah satu pertimbangan dalam penggunaan bahan kayu sebagai bahan konstruksi.Kayu merupakan bahan yang mudah mengalami kerusakan akibat faktor iklim karena pelapukan dan serangan organisme perusak kayu seperti rayap (Ningsih, 2016).

\section{Metodologi Penelitian}

Rumah kayu yang menjadi objek penelitian dalam tulisan ini diambil di daerah tepian sungai yang berada di kelurahan Kelurahan Bansir Laut, Kecamatan Pontianak Tenggara.Beberapa wilayah di Kelurahan Bansir Laut merupakan daerah tepian sungai Kapuas, yang berupa permukiman dengan kepadatan yang cukup tinggi. Rumah-rumah di tepian sungai sebagian besar menggunakan struktur kayu. Dalam penelitian ini dipilih beberapa sampel rumah dengan pertimbangan dalam pemilihan adalah letak bangunan terhadap sungai, material bangunan yang digunakan, jumlah lantai dan dan bentuk bangunan.Letak rumah-rumah yang menjadi sampel dalam penelitian ini adalah rumah yang berdiri di atas tanah yang selalu 
terendam air sepanjang tahun (tetap terendam dalam kondisi surut). Bangunan rumah yang dipilih sebagai sampel adalah bangunan rumah 1 lantai dengan seluruh material pada bangunan tersebut menggunakan kayu. Bentuk yang diambil bervariasi karakternya terutama pada bentuk massa bangunan, bentuk atap dan dinding bangunan.

Metode penelitian yang digunakan untuk mengumpulkan data penelitian adalah teknik observasi, yaitu dengan melakukan pengamatan secara langsung ke obyek penelitian.Observasi dilakukan dengan mengisi lembar observasi yang telah disiapkan.Data diolah dengan pendekatan kualitatif khususnya dalam mendeskripsikan konstruksi rumah kayu pada masing-masing objek sampel. Kemiripan yang ditemui dikelompokkan kemudian dilihat kedekatannya untuk kemudian dapat diperoleh kesimpulan.

Berdasarkan kriteria tersebut, dipilih 5 sampel rumah yang berada pada jalur merah (dapat dilihat pada peta Gambar 1berikut :

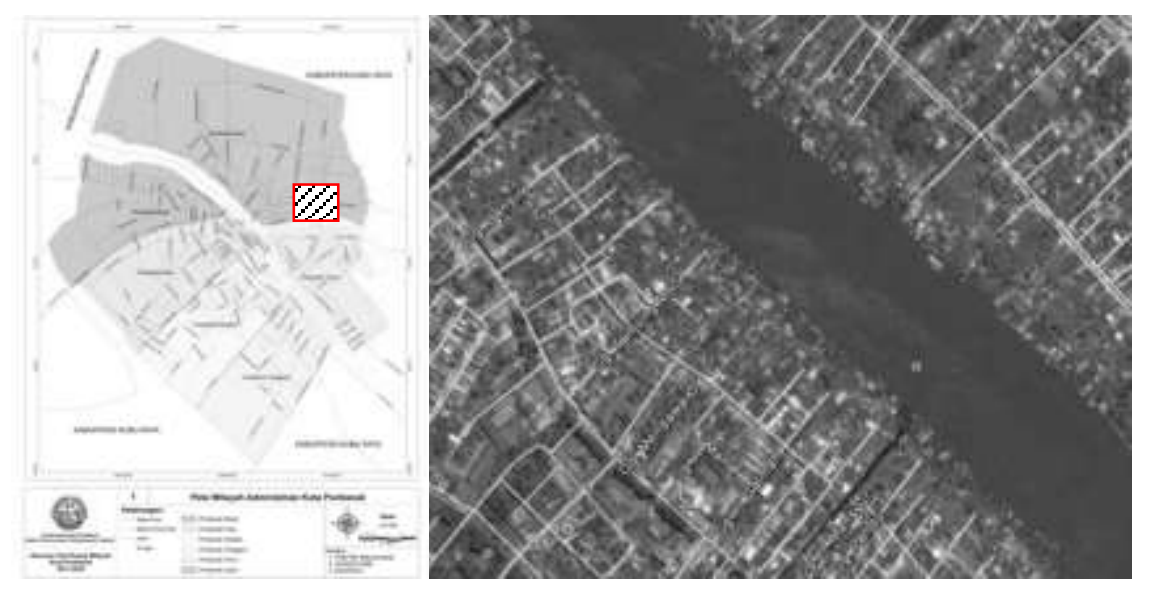

Gambar 1. Lokasi Sampel Rumah pada peta Kota Pontianak (kiri) dan peta daerah tepian sungai Kelurahan Bansir Laut (kanan)

Sumber: Pemkot Kota Pontianak; Google Maps, 2016

\section{Pembahasan: Rumah Kayu Pada Rumah Tepian Sungai Kapuas}

Penggunaan kontruksi kayu pada rumah kayu di tepian sungai Kapuas dalam tulisan ini di deskripsikan berdasarkan komponen bagian-bagian bangunan yaitu pondasi, atap, rangka, dan dinding bangunan. Sampel bangunan yang dipilih untuk diteliti adalah bangunan yang seluruhnya menggunakan material kayu mulai dari pondasi, lantai, dinding sampai rangka atap.

\section{Pondasi Bangunan}

Pada bangunan rumah kayu yang di teliti, pondasi yang digunakan berupa tiang-tiang kayu yang ditancapkan menerus sampai tanah atau dikenal dengan istilah pondasi tiang tongkat.Pondasi ini terdiri dari dua batang kayu alas yang diletakkan di bagian paling dasar yang berhubungan dengan tanah.Di atas kayu alas diletakkan lagi 2 batang kayu dengan posisi menyilang dengan kayu alas yang disering disebut dengan kayu laci.Kayu laci dipasang di samping kiri dan kanan kayu tongkat sebagai penguat pondasi dan ditumpukan langsung di kayu alas.(Gambar 2) 


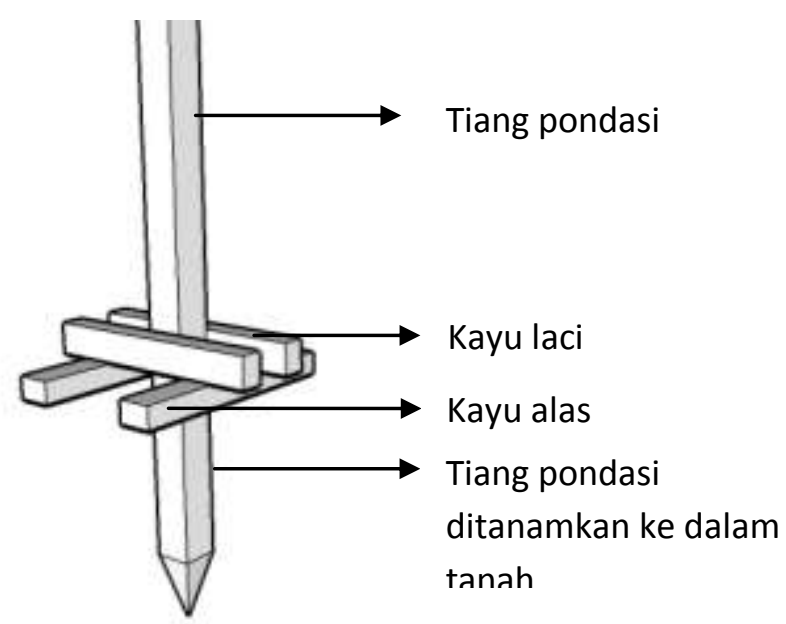

Gambar 2.Detail Pondasi Rumah

Sumber: Ilustrasi Penulis, 2016

Tiang-tiang pondasi dipasang dengan jarak 1-1.5 meter antar tiang pondasi (Gambar 3) Antar titik-titik pondasi dihubungkan dengan balok kayu horizontal yang berfungsi sebagai pengikat antar pondasi sekaligus berfungsi sebagai tumpuan balok lantai. Balok ini sering disebut dengan balok keep yang dipasang pada ketinggian yang disesuaikan dengan ketinggian muka air sungai tertinggi. Selain itu, digunakan pula balok-balok diagonal yang menghubungkan 2 sampai 3 tiang pondasi, dengan susunan yang bervariasi.Kelompok tiang pondasi pertama dipasang dari kiri bawah menuju kanan atas. Pada kelompok tiang kedua dipasang dari kiri atas menuju kanan bawah dan seterusnya dengan susunan yang berulang.Di temui pula balok diagonal yang dipasang saling bersilangan di kiri dan kanan tiang-tiang pondasi atau yang diletakkan disetengah ketinggian pondasi.Fungsi balok diagonal ini adalah sebagai penguat tiang-tiang pondasi yang selalu menerima beban gelombang air.

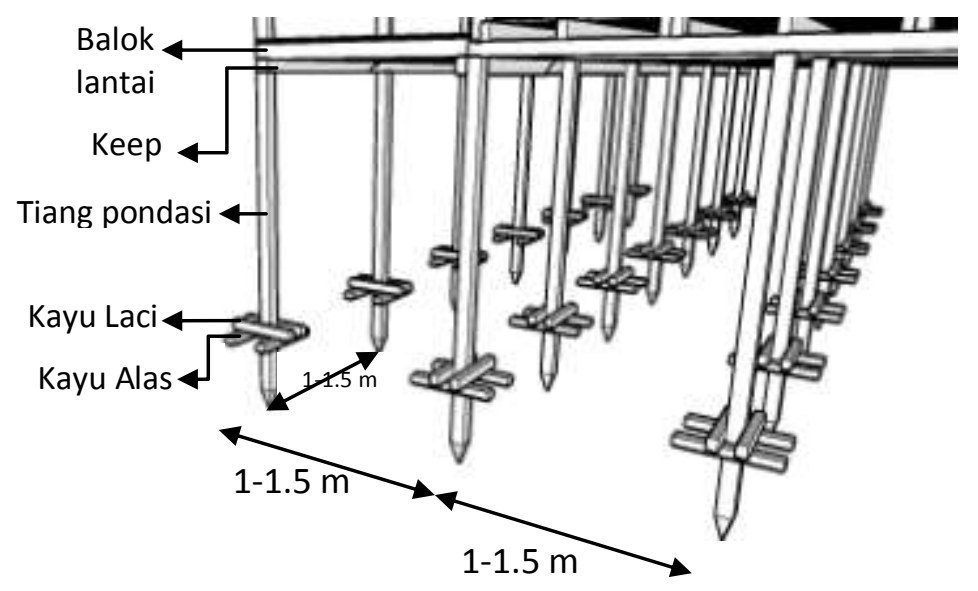

Gambar 3.Susunan Tiang Pondasi Rumah

Sumber: Ilustrasi Penulis, 2016 


\section{Rangka bangunan}

Sistem struktur utama pada bagian badan bangunan merupakan struktur rangka yang terdiri dari batang-batang vertikal berupa tiang-tiang kayu dan batang-batang horizontal berupa balokbalok kayu.Tiang-tiang diletakkan dibagian sudut dari setiap ruang dan bangunan.Tiang-tiang tambahan antara tiang tiang sudut di letakkan sesuai dengan ukuran ruang. Diletakkan 1-4 tiang antara tiang-tiang sudut, dengan jarak 1-1.5 meter. Ada tiang struktur utama yang berada langsung di atas tiang pondasi namun ada yang tidak berada langsung diatas tiang pondasi, namun bertumpu diatas balok yang menghubungkan tiang-tiang pondasi (balok keep). (Gambar 4)

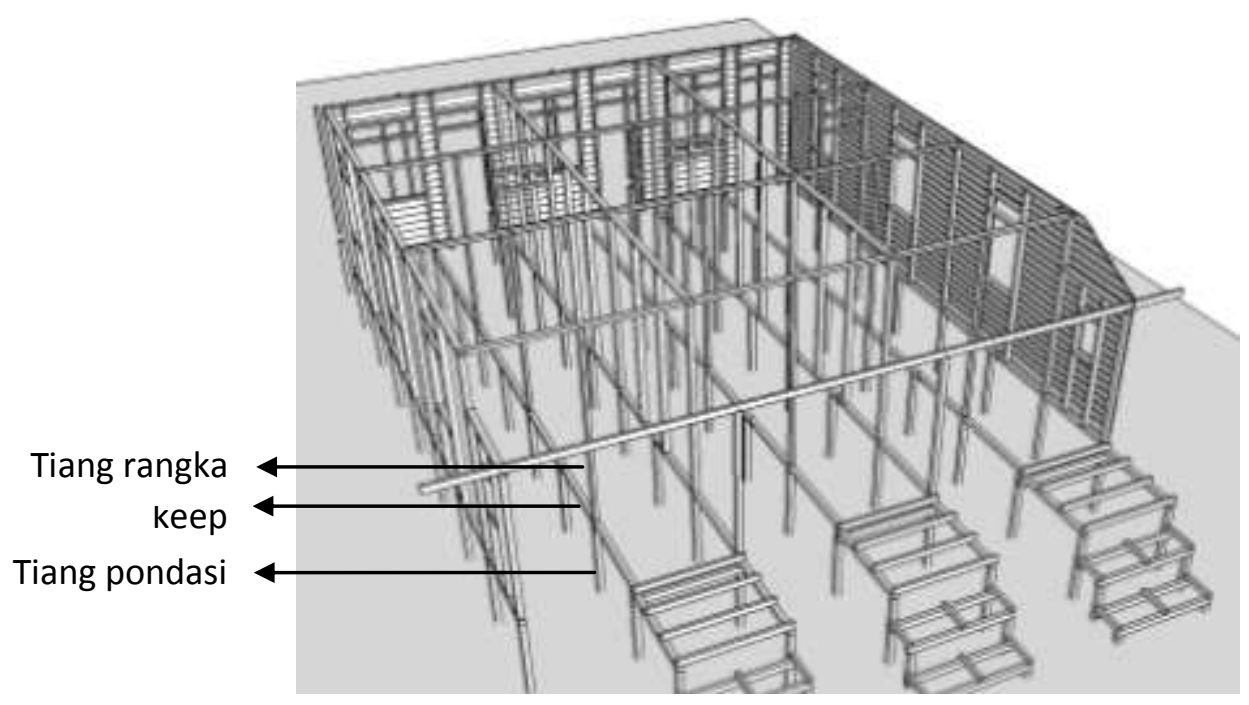

Gambar 4.Hubungan Rangka Bangunan dengan Tiang Pondasi Rumah Sumber: Ilustrasi Penulis, 2016

Peletakan tiang-tiang vertikal dan balok-balokhorizontal pada rangka bangunan sangat tergantung dari bentuk denah dan susunan ruang-ruang yang ada.Peletakan tiang-tiang dapat dilihat susunannya pada denah bangunan rumah. Tiang-tiang tersebut didirikan dengan jarak 11.5 meter disekeliling bangunan dan pada bagian ruang yang didirikan dinding. Untuk ruang yang lebih luas atau ruang tanpa dinding digunakan tiang-tiang dengan jarak 2-3 meter.(Gambar 5)

Peletakan balok-balok horizontal tergantung pada ketinggian bangunan, peletakan pintu dan jendela serta konstruksi rangka atap.Balok horizontal paling atas atau disebut balok penutup menghubungkan tiang-tiang di bagian atas.Balok ini sekaligus menjadi bagian rangka atap yang berfungsi sebagai tumpuan kuda-kuda dari rangka atap. Diantara balok keep dan balok penutup bagian atas, ditambahkan dengan balok horizontal atau balok sengkang. Penambahan ini bervariasi jumlahnya dari satu sampai tiga balok.Adapula rumah yang tidak menggunakan penambahan balok diantara balok atas dan bawah. Pada bagian pintu, jendela dan ventilasi dilakukanpenambahan balok horizontal karena balok tersebut sekaligus digunakan untuk memasang daun pintu maupun daun jendela. 


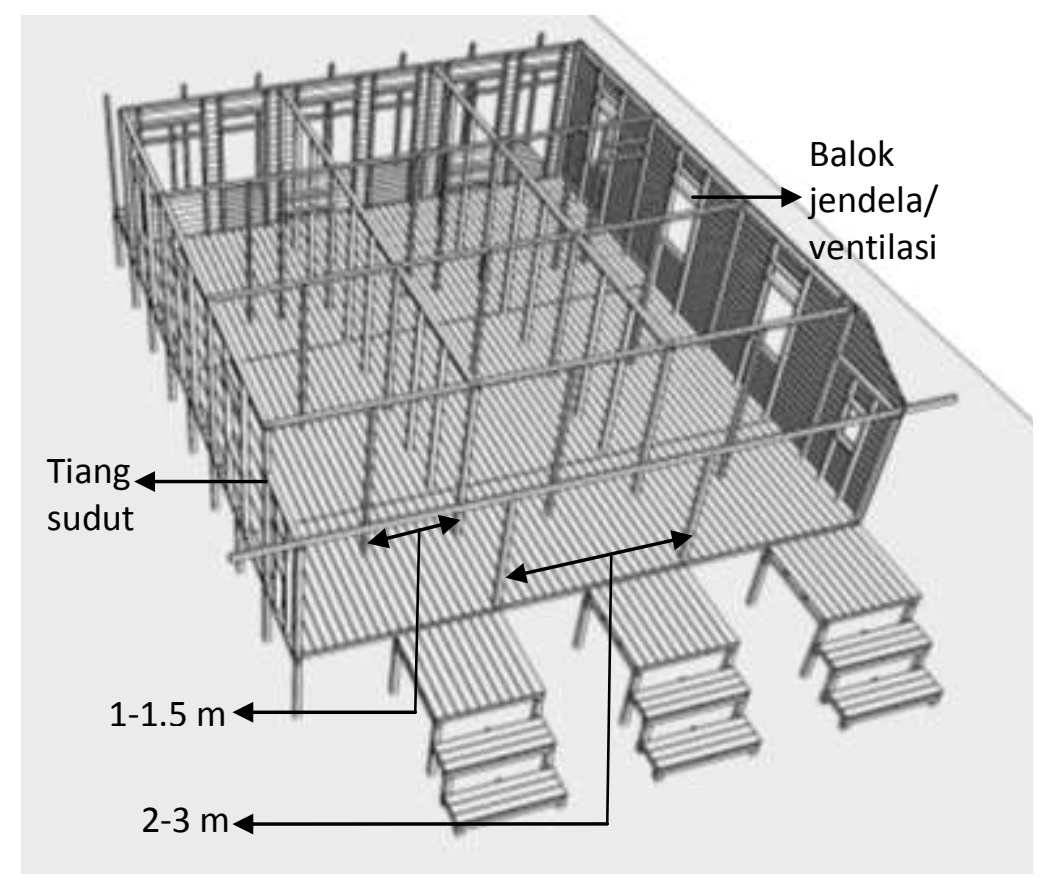

Gambar 5.Peletakan Tiang-Tiang Rangka Bangunan Sumber: Ilustrasi Penulis, 2016

\section{Lantai}

Lantai pada bangunan yang menjadi sampel penelitian merupakan lantai papan.Susunan dari lantai papan ini beragam, namun secara garis besar dipasang menjadi memanjang sesuai dengan panjang papan yang digunakan. Tumpuan papan adalah balok horizontal bagian bawah, yang sering dan dikenal dengan nama balok lantai. Balok lantai bertumpu pada balok dibawahnya yang sekaligus berfungsi sebagai pengikat antar titik-titik pondasi (balok keep). Gambar penggunaan lantai papan dan susunan dapat dilihat pada Gambar 6dan Gambar 7

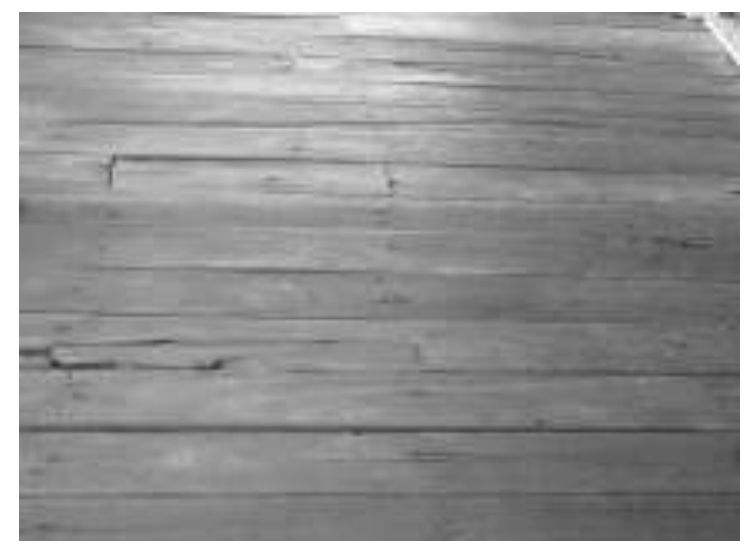

Gambar 6. Penyusunan Lantai Papan Sumber:Survey, 2015 

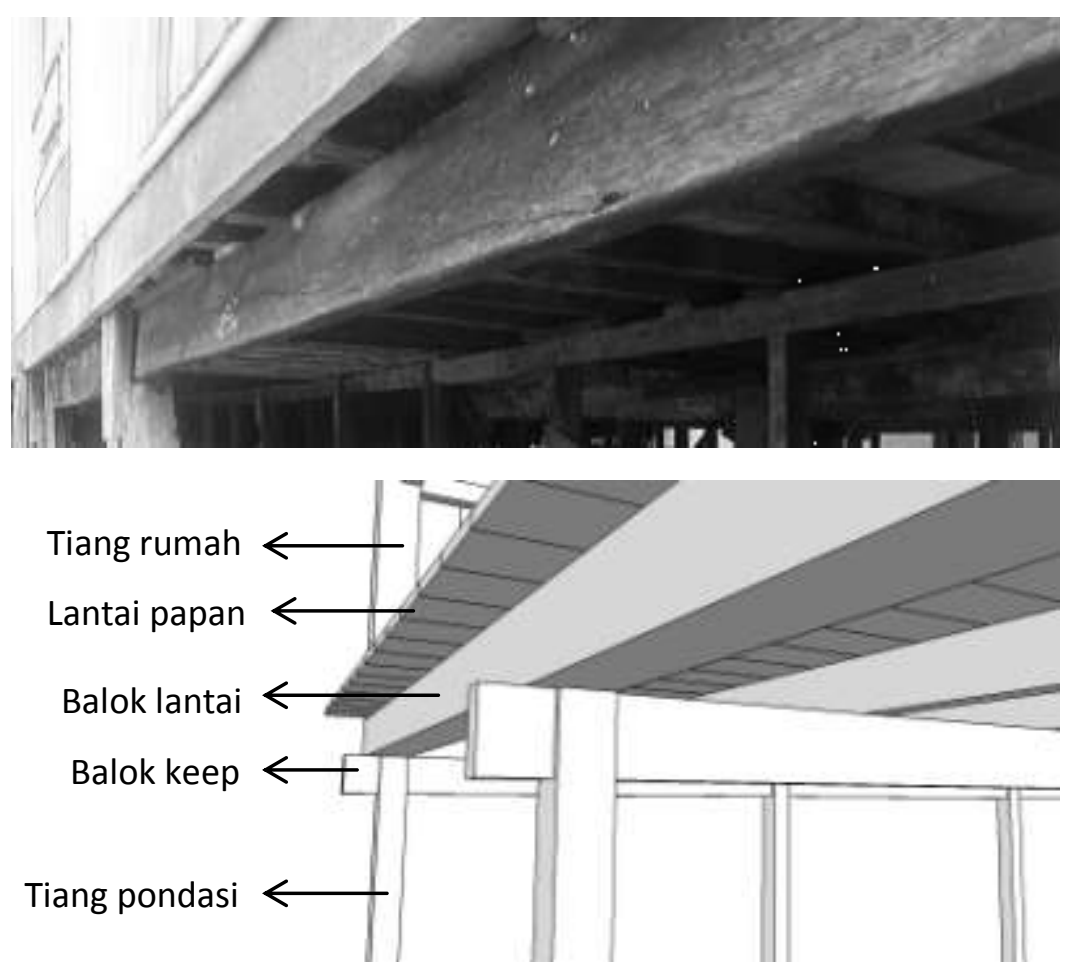

Gambar 7. Balok Lantai pada Kontruksi Lantai Papan

Sumber: Survey dan Ilustrasi Penulis, 2016

\section{Dinding Bangunan}

Ada 2 jenis tipe penyusunan dinding papan pada bangunan rumah yang diteliti.Tipe pertama dinding disusun secara vertikal yang ditemukan pada bangunan sampel 2. Tipe kedua dinding disusun secara horizontalyang ditemukan pada sampel 1,3,4 dan 5 .

Dinding papan yang disusun secara vertikal menghasilkan bentuk fasad bangunan yang memilliki unsur garis garis vertikal.Dinding papan dengan tipe vertikal langsung dipasang pada tiang-tiang kayu dan balok sengkang.Pemasangan hanya menggunakan paku yang digunakan disetiap pertemuan dinding papan dan balok sengkang.Dinding dipasang dengan rapat untuk menghindari celah terbuka pada dinding.Papan yang digunakan panjangnya menyesuaikan dengan ketersediaan bahan.Papan disambung di bagian pertemuan dengan sengkang jika panjang tidak sesuai dengan kebutuhan.Bentuk konstruksi dinding papan yang dipasang vertikal dapat dilihat pada Gambar 8berikut. 

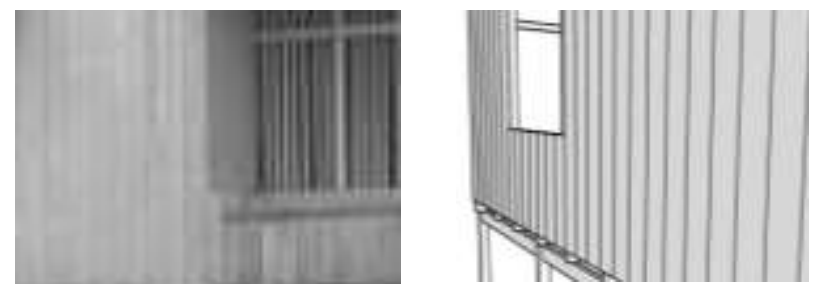

Gambar 8.Gambar dan Ilustrasi Susunan Dinding secara Vertikal Sumber: Survey dan Ilustrasi Penulis, 2016

Konstruksi dinding dengan penyusunan berbentuk horizontal menghasilkan bentuk fasad dengan garis-garis horizontal (Gambar 9).Pada rumah dengan dinding tersusun horizontal, balok-balok sengkang lebih sedikit digunakan, umumnya hanya digunakan untuk memasang pintu, jendela dan ventilasi. Hal ini bisa dipahami bahwa dinding kemungkinan memberikan tambahan kekakuan pada rangka utama (kekakuan tiang-tiang bangunan)
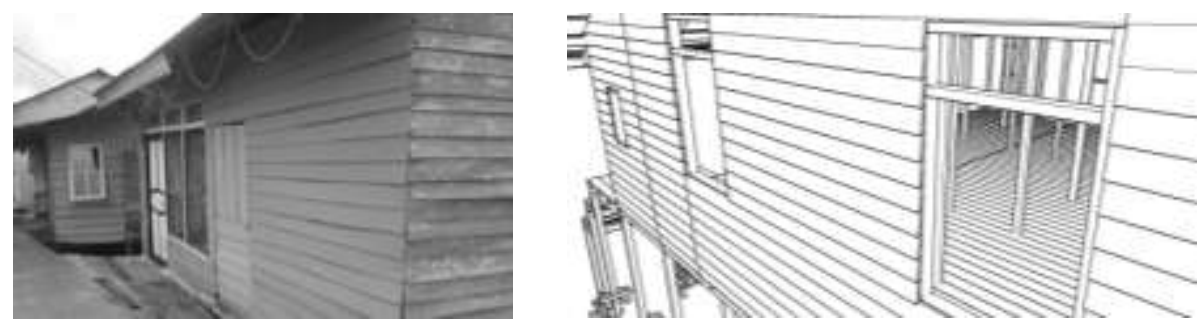

Gambar 9.Gambar dan Ilustrasi Susunan Dinding secara Horizontal Sumber: Survey dan Ilustrasi Penulis, 2016

\section{Atap bangunan}

Bangunan-bangunan yang menjadi sampel dalam penelitian umumnya hanya memiliki 2 jenis bentuk atap yaitu limas dan pelana. 3 sampel merupakan bangunan dengan atap pelana, 1 sampel dengan atap limas dan 1 sampel dengan atap limas yang dikombinasi dengan atap pelana. Bentuk rangka kuda-kuda tersebut juga dipengruhi oleh ukuran rumah khususnya panjang dan lebar bangunan.

Rangka kuda-kuda atap memiliki struktur yang terhubung dengan struktur rangka di bawahnya.Bagian teratas daristruktur rangka badan bangunan menggunakan balok horizontal (balok penutup) yang berfungsi memperkaku strukturrangka di bagian atas.Balok penutup tersebut sekaligus digunakan untuk rangka atap.Kayu yang dipasang miring untuk membentuk kemiringan atap langsung bertumpu pada balok penutup tersebut.(Gambar 10). 


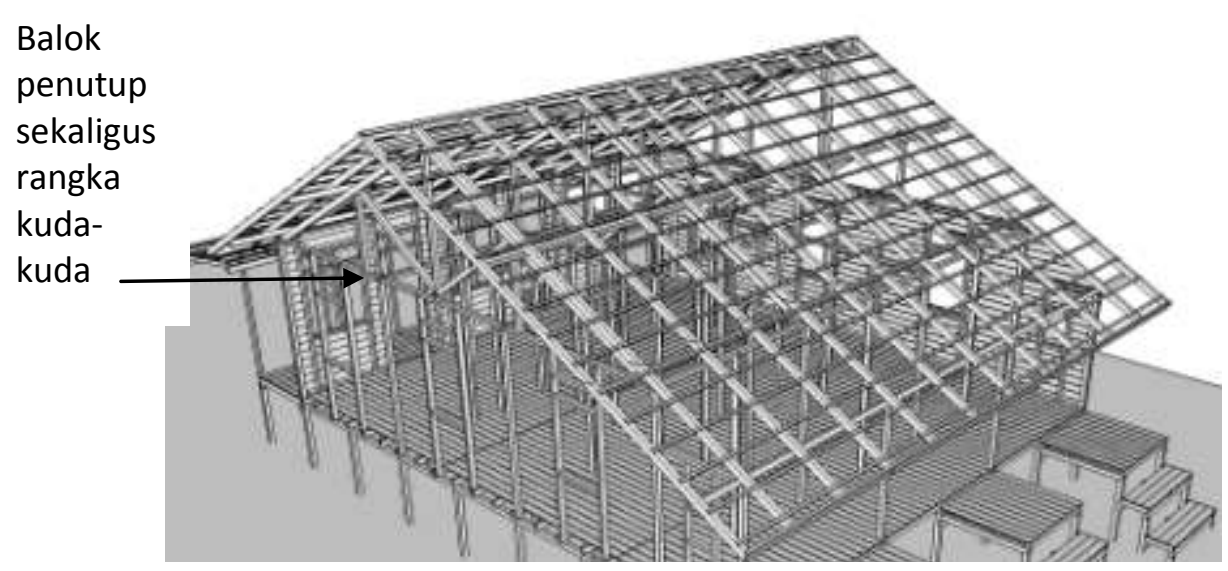

Gambar 10.Ilustrasi Rangka Kuda-Kuda

Sumber: Ilustrasi Penulis, 2016

Jumlah elemen-elemen rangka atap yang digunakan dalam suatu stuktur rangka atap sangat tergantung pada bentangan dan bentuk.Pada bentuk bangunan sederhana dengan bentang bangunan tidak terlalu besar struktur rangka atap hanya ditambahkan dua elemen struktur yang dipasang vertikal dan miring untuk menopang kemiringan atap.Namun, untuk bangunan yang lebih panjang dan bentuk lebih komplek elemen struktur yang digunakan lebih banyak(Gambar 11).

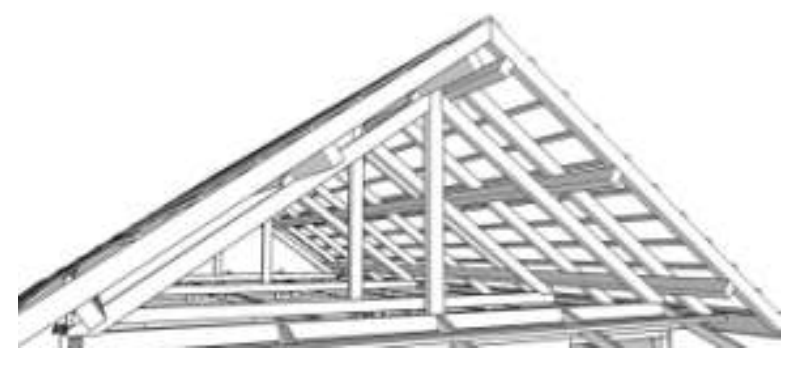

a. Rangka kuda-kuda tanda penambahan balok miring/horizontal

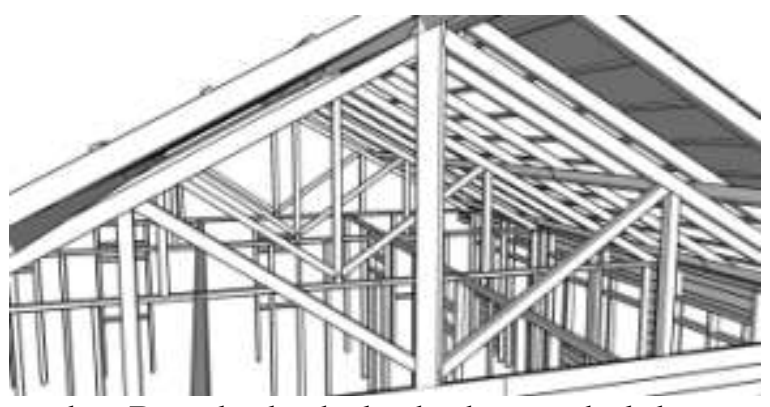

b. Rangka kuda-kuda dengan balok miring/horizontal

Gambar 11.a dan b: Ilustrasi Bentuk Rangka Kuda-Kuda

Sumber: Ilustrasi Penulis, 2016

\section{Kesimpulan}

Bangunan rumah-rumah yang diteliti di tepian sungai Kapuas merupakan bangunan kayu mulai dari pondasi, lantai, rangka, sampai atap.Antara satu bagian dengan bagian lain dalam bangunan tidak dapat dipisahkan, karena satu komponen bagian bangunan menjadi komponen bagian lain dari bangunan.Balok penghubung antar pondasi menjadi bagian dari konstruksi lantai, sebagai tumpuan balok lantai.Balok lantai sekaligus sebagai pengaku bagian rangka bangunan.Balok penutup bagian paling atas darirangka sekaligus sebagai balok tumpuan untuk rangka atap.Keseluruhan bagian bangunan menjadi kesatuan secara sistem, yang saling terkait dan berhubungan. 


\section{Daftar Pustaka}

Abdurachman., Nurwati Hadjib. (2006). Pemanfaatan Kayu Hutan Rakyat Untuk Komponen Bangunan. PROSIDING Seminar Hasil Litbang Hasil Hutan 2006 : 130-148: Bogor

Hidayat, Husnul. (2014). Konteks Ekologi Kota Tepian Sungai dalam Perspektif Lokalitas Bahan Bangunan. Membangun Karakter Kota Berbasis Lokalitas. Architecture Event 2014

Hidayati, Zakiah. (2012). Sistem Struktur dan Konstruksi Bangunan Vernakula Rumah Suku Kutai Tenggarong, Kalimantan Timur . JURNAL EKSIS Vol.8 No.1, Mar 2012: 2001 2181

Khaliesh, Hamdil., Indah Widiastuti., Bambang Setia Budi. (2012). Karakteristik Permukiman Tepian Sungai Kampung Beting di Kota Pontianak. Prosseding Temu Ilmiah IPLBI 2012. Bandung

Ningsih, Deffi Surya., Za'aziza Ridha Julia., Larissa Hilmi., Leo Darmi. (2016). Rayap Kayu (Isoptera) Pada Rumah-Rumah Adat Minangkabau Di Sumatera Barat diakses online padahttp://artikel.dikti.go.id/index.php/PKM-P/article/viewFile/23/23 pada tanggal 28 September 2016

Puspantoro, Ign Benny, Ir. (2005). Konstruksi Bangunan Gedung : Sambungan Kayu Pintu Jendela. Penerbit Andi : Yogyakarta

Zain, Zairin. (2012). Pengaruh Aspek Eksternal pada Rumah Melayu Tradisional di kota Sambas. Jurnal NALARSs Vol 11 No. 2 Juli 2012 .Universitas Muhammadiyah Jakarta. Jakarta

Zain, Zairin., Indra Wahyu Fajar. (2014). Tahapan Konstruksi Rumah Tradisional Suku Melayu di Kota Sambas Kalimantan Barat. Jurnal Langkau Betang Vol 1 No. 12014 . Universitas Tanjungpura. Pontianak. 